\title{
Spatio-temporal dynamics in the dissolved nutrient waste plume from Norwegian salmon cage aquaculture
}

\author{
H. M. Jansen ${ }^{1,2, *}$, O. J. Broch ${ }^{3}$, R. Bannister ${ }^{1}$, P. Cranford ${ }^{4}$, A. Handå ${ }^{3}$, V. Husa ${ }^{1}$, \\ Z. Jiang ${ }^{5}$, T. Strohmeier ${ }^{1}$, Ø. Strand ${ }^{1}$ \\ ${ }^{1}$ Institute of Marine Research, Nordnesgaten 50, 5005 Bergen, Norway \\ ${ }^{2}$ Wageningen University and Research, Wageningen Marine Research (WMR), PO Box 77, 4400 AB Yerseke, The Netherlands \\ ${ }^{3}$ SINTEF Ocean, Postboks 4762 Torgarden, 7465 Trondheim, Norway \\ ${ }^{4}$ Fisheries and Oceans Canada, St. Andrews Biological Station, 125 Marine Science Dr., Saint Andrews, \\ New Brunswick E5B 0E4, Canada \\ ${ }^{5}$ Yellow Sea Fisheries Research Institute, Chinese Academy of Fishery Sciences, 106 Nanjing Road, Qingdao, \\ Shandong Province, PR China
}

\begin{abstract}
The aim of this study was to define the waste plume dynamics around a salmon farm in Norway. Systematic water sampling and numerical modeling were implemented to define nutrient concentrations in the upper water column at long-term (seasonal) and short-term (between and within days) time scales. Nutrient enhancement was observed for ammonium only, while the concentrations of orthophosphate and organic wastes were never higher than the background values. The spatial magnitude of cage effluent dispersion was limited. Empirical results detected enhanced concentrations up to $100 \mathrm{~m}$ down-current of the farm when fish biomass was high. Model results showed that the zone of influence could occasionally reach to $>1000 \mathrm{~m}$. In the first year of production, when fish biomass was low, no enhancement was detected, and in April and September of the following year, average ammonium concentrations were respectively 0.2 and $0.8 \mu \mathrm{M}$ above the background concentrations. Taking the ambient seasonal variability into account, this resulted in 1.6 times higher concentrations for both sampling months. The measured short-term temporal variability in nutrient concentrations near the cages varied up to 2 times from day to day and were 3.5 times higher in the evening compared to the morning. As seasonal investigations were performed in the morning, maximum enhancement was likely underestimated. The rapid decrease in nutrient concentrations with increasing distance from the cages suggests that the farm studied here is currently not causing significant degradation of surface water quality. Results of this study contribute to evaluating the potential for ecological mitigation of waste nutrients and provide directions for design of optimized integrated multi-trophic aquaculture facilities.
\end{abstract}

KEY WORDS: Atlantic salmon $\cdot$ Farm scale $\cdot$ Nutrients $\cdot$ Nitrogen $\cdot$ Integrated multi-trophic aquaculture $\cdot$ IMTA $\cdot$ Pelagic $\cdot$ Environmental impact

\section{INTRODUCTION}

While total aquaculture production in Europe is stagnating, rapid growth has been observed in finfish aquaculture in marine waters (FAO 2016). European finfish production in marine waters $(1.8 \mathrm{Mt})$ is prima-

${ }^{*}$ Corresponding author: henrice.jansen@wur.nl rily situated in Norwegian fjords and coastal waters (1.3 Mt) and is dominated by Atlantic salmon Salmo salar production (>90\%). Total finfish mariculture production volume in Europe has doubled over the past decade (FAO 2016), and significant further increase is expected. Growth of marine finfish produc-

(C) The authors 2018. Open Access under Creative Commons by Attribution Licence. Use, distribution and reproduction are unrestricted. Authors and original publication must be credited. 
tion in open sea cages has raised a general concern regarding potential impacts of organic and inorganic waste products on the coastal marine environment (Read \& Fernandes 2003, Mente et al. 2006, Price et al. 2015). Waste products consist of uneaten feed pellets, fecal material and metabolic waste products in dissolved inorganic forms. Dissolved wastes may enhance ambient nutrient levels (Troell et al. 2003, Sarà 2007, Price et al. 2015), potentially influencing primary and secondary production (Cloern 2001, Price et al. 2015), while the majority of particulate matter sinks to the seabed and has the potential to change the structure and function of benthic communities and biochemical functioning of the sediment (Kalantzi \& Karakassis 2006, Kutti et al. 2007, Valdemarsen et al. 2012, Bannister et al. 2014). Mass balance models have indicated for a range of fish species that $20-70 \%$ of nitrogen supplied with the fish feed is released as excess nutrients (Islam 2005). For farmed salmon, it is estimated that these numbers approximate $60-80 \%$ for both nitrogen and phosphorus (Mente et al. 2006, Bergheim \& Braaten 2007, Wang et al. 2012).

One of the major challenges for the sustainable development of open-water finfish culture is to minimize waste discharges and/or to exploit the discharged nutrients. Integrated multi-trophic aquaculture (IMTA) has been proposed as a mitigation approach that exploits the waste nutrients released through intensive fish farming (Neori et al. 2004, Chopin et al. 2008, Soto 2009, Granada et al. 2016). IMTA is based on the principle of waste recycling and includes farming of multiple complementary species from different trophic levels in a manner that allows the waste of one species to be recaptured or converted into a resource that is utilized by other species (Ryther et al. 1975). Recent IMTA development for finfish aquaculture often includes suspended bivalves to recapture solid wastes and seaweeds for extracting the inorganic nutrients (Chopin et al. 2005, 2008, Granada et al. 2016) and thus focuses on biomitigation in the euphotic zone. Understanding the complex dynamics at cage aquaculture sites involving the physical environment and its effects on waste dispersal patterns is vital for estimating IMTA efficiency.

Environmental impact assessments indicate that the spatial extent of waste dispersal is often limited to a few hundred meters from the farm (Brooks \& Mahnken 2003, Sarà et al. 2004, Yokoyama et al. 2006, Bannister et al. 2016). These studies are mostly directed towards deposition of aquaculture wastes towards the bottom (vertical transport), whereas less is known about pelagic dispersion (horizontal transport) of dissolved organic and inorganic nutrients released by sea cage cultures (Sarà 2007, Handa et al. 2012, Husa et al. 2014). A few studies have reported enhanced water column particle and/or nutrient concentrations in the vicinity of marine finfish cages, while minimal or no enhancement was presented in several other studies (see Price et al. 2015 and references therein). Far-field impact studies targeting horizontal transport of aquaculture discharges in the euphotic zone are rare. Maximum impacted distance has been reported by Sanderson et al. (2008), who presented ammonium concentrations of $1 \mu \mathrm{M}$ above background values up to $200 \mathrm{~m}$ distance down-current from sea cages. The varying and conflicting results observed for distribution patterns of aquaculture discharges between study sites can be attributed to a number of factors, including variations in total area used for culture, degree of intensification, production level, profile of the water body, bathymetry of the system, hydrodynamic conditions and water-exchange mechanisms of the sites (Islam 2005). Moreover, waste plume dynamics within a site are subject to temporal factors including seasonal aspects such as fish biomass, but also hydrodynamic conditions including tidal cycles and wind-induced current patterns, as well as diurnal patterns induced by feeding regimes and fish activity.

The current study focuses on horizontal dissolved waste dispersal from salmon cage farming in Norwegian coastal areas. How aquaculture wastes are distributed in these areas is largely unknown, and since Norwegian coastal and fjord systems differ considerably from other cultivation sites in terms of bathymetry, depth, hydrodynamics and environmental conditions such as temperature and phytoplankton concentrations, waste distribution might vary considerably from other cultivation areas. Vertical transport of aquaculture waste particles in fjords has been studied by Kutti et al. (2007) and Valdemarsen et al. (2012) and modeled by Bannister et al. (2016), demonstrating the importance of hydrodynamic conditions on waste dispersal in deep fjords. Horizontal nutrient dispersal has been studied at the regional level in the Hardangerfjord (Skogen et al. 2009, Husa et al. 2014), while information on farm-scale waste distribution has only been studied in terms of particle dynamics (Brager et al. 2015). It is expected that Norway's farms of the future will largely increase in size and will be located in dynamic coastal areas.

Here we aimed to quantify dissolved nutrient concentrations down-current of a large-scale commercial Atlantic salmon farm to define near- to far-field 

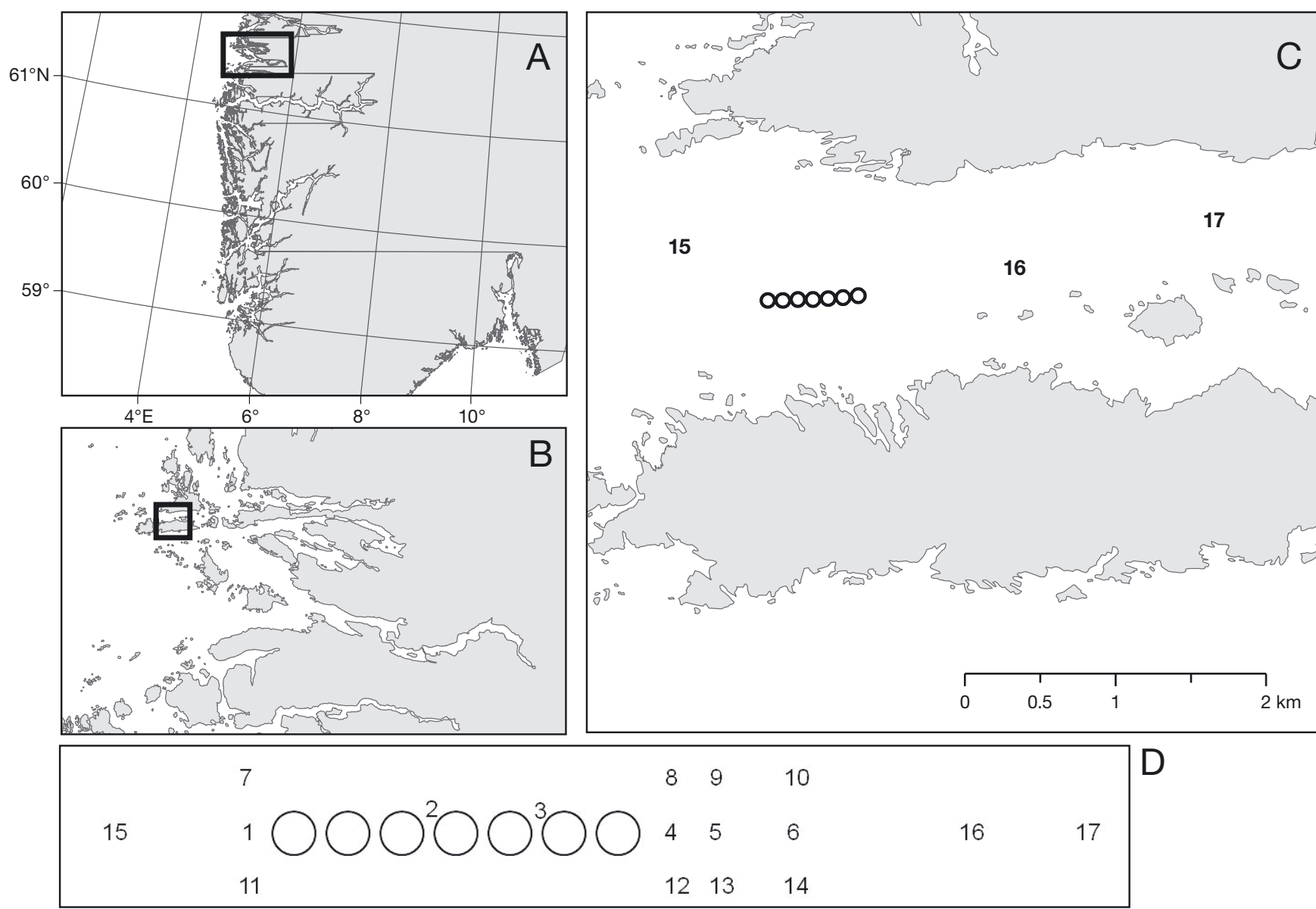

Fig. 1. (A,B) Location of study site in western Norway. (C) Study site (Flåtegrunnen), showing the location of salmon net pens (circles) and reference sites (Stns 15-17). (D) Outline of the grid survey; circles represent the salmon cages, and numbers indicate the sampling stations included in the systematic water sampling campaigns (see also Table 1)

waste plume dynamics in the euphotic zone of a dynamic coastal system. Systematic water sampling programs were implemented to investigate the shortand long-term temporal variation of dissolved waste plume dynamics. As empirical measurements present an instantaneous recording of environmental conditions, a numerical model was used to further assess the potential extent of the waste plume and to estimate the dynamics at higher temporal and spatial resolutions.

\section{MATERIALS AND METHODS}

\section{Study site and farm management}

To determine the dynamics in nutrients released from salmon aquaculture, a field study was conducted at a large-scale commercial Atlantic salmon farm located close to the open sea in central Norway $\left(61^{\circ} 34.586^{\prime} \mathrm{N}, 4^{\circ} 48.942^{\prime} \mathrm{E}\right.$, Fig. $\left.1 \mathrm{~A}, \mathrm{~B}\right)$. The farm consisted of 7 circular net pens $(\varnothing 80 \mathrm{~m})$ situated in a row parallel to the dominant current direction (Fig. 1C). Historical data from the farm showed that current patterns at this location were primarily driven by tidal cycles. The sides of the cages were $20 \mathrm{~m}$ deep, and the bottom was conical with a maximum depth of $30 \mathrm{~m}$. Average depth below the farm was 75-200 m.

The farm was operated in a 16 mo production cycle; juveniles of approximately $100 \mathrm{~g}$ were stocked in August 2012 with a density of 200000 ind. cage ${ }^{-1}$ and harvested between September and December the following year. Farm management was based on an all-in-all-out principle at cage level, and therefore no sorting was applied throughout the production cycle. The provided pelleted fish feed increased gradually as the production cycle progressed, but was also dependent on ambient temperature, and varied between 82 and $724 \mathrm{t} \mathrm{mo}^{-1}$ (Fig. 2). Generally, feed was supplied to the cages between 07:00 and 19:00 h, 


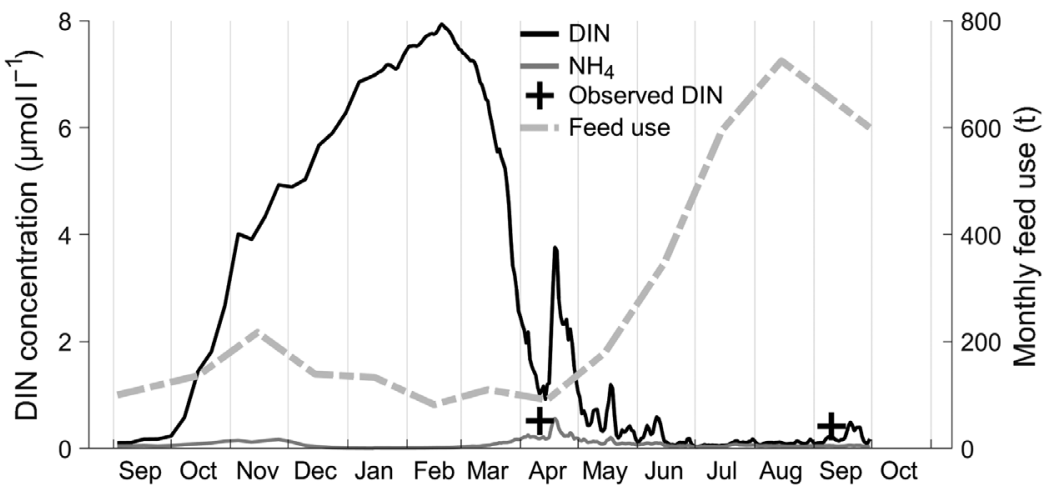

Fig. 2. Time series of observed and simulated background depth-integrated $(0-10 \mathrm{~m})$ dissolved inorganic nitrogen $\left(\mathrm{DIN}=\mathrm{NO}_{3}{ }^{-}+\mathrm{NH}_{4}{ }^{+}\right)$and $\mathrm{NH}_{4}{ }^{+}$concentrations at Flåtegrunnen from September 2012 to September 2013 based on results from the numerical model. Monthly feed use for the farm is also shown

with a period of food exclusion between 12:00 and 14:30 h. Approximately $60 \%$ of the feed was supplied in the morning period and $40 \%$ in the afternoon.

\section{Water sampling campaigns}

Three systematic water sampling campaigns were carried out at 6 mo intervals in September 2012, April 2013 and September 2013. Accompanying parameters were investigated to evaluate hydrodynamic and environmental conditions during the sampling programs (Jansen et al. 2016), but were not intended to provide information on long-term environmental variations at the farm site. Current meters (SD6000, Sensor Data AS) and CTD probes (STD/CTD 204, SAIV) were installed at farming and reference stations over a period of 2-4 d during each sampling campaign.

During each sampling campaign, a grid survey including 17 stations was conducted (Fig. 1D). This grid design, including a gradient moving away from the farm and 3 reference stations, was chosen based on Husa et al. (2014), Jansen et al. (2016) and V. Husa (unpubl. data). The grid consisted of a vertical transect along the farm including 6 stations and 2 reference stations which were sampled in triplicate and an additional 8 stations and 1 reference station that were sampled once (Table 1). Sampling was performed in the morning after fish feeding commenced and at least $1 \mathrm{~h}$ after the tides turned to guarantee a onedirectional current direction throughout the sampling period. Stations were sampled in a haphazard manner by means of 2 boats to minimize the total timespan for sample collection to 1.5-2.5 h. Depth transects were obtained at each station by water sampling at regular intervals from the surface up to depth of the fish cages $(1,5,10,15$ and $20 \mathrm{~m}$ depth), and depth profiles for temperature, fluorescence and salinity were simultaneously obtained by running an STD/CTD 204 profile up to $40 \mathrm{~m}$ depth. Water samples were analyzed for total nitrogen and phosphorus (TN, TP) and dissolved inorganic nitrogen and phosphorus (DIN, DIP).

Short-term temporal variability (within and between days) was determined at selected stations and sampling campaigns, applying a similar depth interval range as described above. Determination of hydrodynamic conditions covered the timespan when short-term temporal variability measurements were performed. To determine daily variability in water quality parameters, Stns 1, 3, 4 and 16 were sampled again the following day during the sampling campaign in April and September 2013. The same parameters as included in the seasonal study were analyzed (TN, TP, DIN, DIP and CTD profiles). To compare concentrations between the 2 consecutive days, a similarity index was introduced $\left(\mathrm{Conc}_{\mathrm{day} 1} / \mathrm{conc}_{\mathrm{day} 2}\right)$. This similarity index indicates when concentrations between the 2 sampling points were similar; values $<1$ indicate that conc $_{\text {day } 1}<$ conc $_{\text {day } 2}$, and values $>1$ in-

Table 1. Experimental set-up for the systematic water sampling campaign. Farm = Stns 2 and 3, ref = Stns 15-17, see Fig. 1C,D for the station survey grid

\begin{tabular}{|c|c|c|c|c|c|c|c|c|c|c|c|c|c|c|c|c|c|}
\hline Stn & 1 & 2 & 3 & 4 & 5 & 6 & 7 & 8 & 9 & 10 & 11 & 12 & 13 & 14 & 15 & 16 & 17 \\
\hline $\begin{array}{l}\text { Distance to } \\
\text { farm (m) }\end{array}$ & 100 & $<5$ & $<5$ & 100 & 200 & 400 & 100 & 100 & 200 & 400 & 100 & 100 & 200 & 400 & 1000 & 1000 & 1500 \\
\hline \multicolumn{18}{|c|}{ No. of replicate measurements } \\
\hline Sep 2012 & & 1 & 1 & 1 & 1 & 1 & & 1 & 1 & 1 & & 1 & 1 & 1 & 1 & 1 & 1 \\
\hline Apr 2013 & 3 & 3 & 3 & 3 & 3 & 3 & 1 & 1 & 1 & 1 & 1 & 1 & 1 & 1 & 3 & 3 & 1 \\
\hline Sep 2013 & 3 & 3 & 3 & 3 & 3 & 3 & 1 & 1 & 1 & 1 & 1 & 1 & 1 & 1 & 3 & 3 & 1 \\
\hline
\end{tabular}


dicate that conc $_{\text {day } 1}>$ conc $_{\text {day2 }}$. Standardized variance was calculated by identifying the difference from the similarity index for each sampling point. If standardization had not been applied, average variance could have resulted in a value of 1 (= zero variance), as differences could be both above and below 1. Additionally, variations within 1 day (diurnal variability) were determined in September 2013 close to Stn 2 (2-3 m from the west side of the fish cage). Triplicate samples were taken at 06:00, 06:30, 07:00 and 08:00 $\mathrm{h}$ and every $2 \mathrm{~h}$ thereafter until 20:00 h, with the last sampling performed at 21:00 h. For these samples, only ammonium (total ammonium nitrogen, TAN) concentrations were determined.

During all sampling campaigns, water samples were processed on board a research vessel where the samples (1 l) were divided over different nutrient vials. Subsamples for determination of dissolved $(20 \mathrm{ml})$ and total nutrient concentrations $(100 \mathrm{ml})$ were preserved with chloroform and stored at a cool and dark place, and ammonium subsamples $(20 \mathrm{ml})$ were immediately frozen at $-20^{\circ} \mathrm{C}$.

\section{Laboratory analysis}

Samples for nitrate $\left(\mathrm{NO}_{3}\right)$, nitrite $\left(\mathrm{NO}_{2}\right)$, phosphate $\left(\mathrm{PO}_{4}\right)$ and silicate $\left(\mathrm{Si}(\mathrm{OH})_{4}\right)$ were analyzed according to standard methods (Parson et al. 1992), and ammonium (TAN) concentrations were analyzed by means of fluorometric analysis (Kérouel \& Aminot 1997, Holmes et al. 1999). Both analyses were adapted for an auto-analyzer. TN and TP were analyzed using spectrophotometric methods as described by Grasshoff et al. (1999).

\section{Data and statistical analysis}

To test the difference between nutrient concentrations measured at farm and reference stations, a 2way nested ANOVA was performed with fixed factors for site (farm versus reference) and station (S2, S3, S15, S16) for each depth interval separately in April and September 2013. Differences in standardized variation (daily variation) between farm and reference stations were analyzed using an independent $t$-test. Statistical analyses were performed using SAS 9.3, and data were checked for homogeneity and normality of variance assumptions (Quinn \& Keough 2002).

\section{Numerical modeling}

A nested, coupled 3D hydrodynamic-ecological model system (SINMOD, Broch et al. 2013) was used to simulate the spread and dilution of ammonium released from the Flåtegrunnen from February to September 2013. The hydrodynamic module solves the primitive Navier-Stokes equations by a finite difference scheme. The model is hydrostatic and uses $z$-coordinates (Slagstad \& McClimans 2005). The ecosystem module includes compartments for concentrations of phytoplankton and nutrients $\left(\mathrm{Si}(\mathrm{OH})_{4}\right.$, $\mathrm{NO}_{3}{ }^{-}-\mathrm{N}, \mathrm{NH}_{4}{ }^{+}-\mathrm{N}$ ) which allows for simulating both physical dilution and uptake by phytoplankton of ammonium. Remineralization of $\mathrm{NH}_{4}{ }^{+}-\mathrm{N}$ into $\mathrm{NO}_{3}{ }^{-}-\mathrm{N}$ is accounted for. There are further states for bacteria, heterotrophic nanoflagellates, ciliates and mesozooplankton in addition to detritus and sediments (Wassmann et al. 2006). In order to study near-field to far-field processes related to fish farming, high-
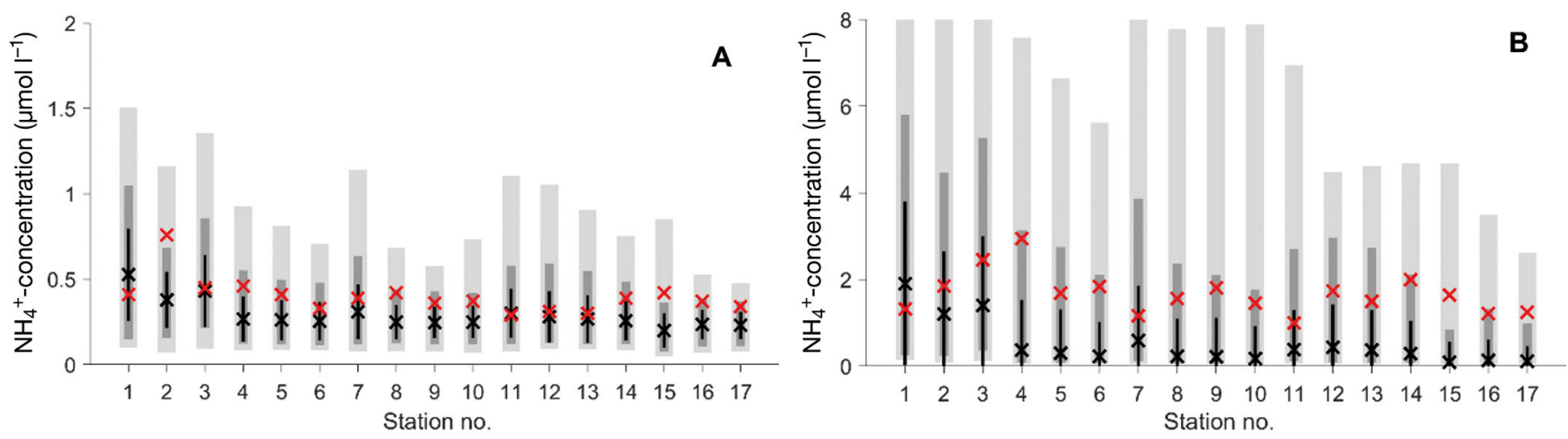

Fig. 3. Comparison between empirical and modeled ammonium concentrations in (A) April and (B) September for each station. Red Xs represent the depth-integrated empirical results. Black Xs represent the median simulated values sampled hourly over the entire month ( $\mathrm{n}=720$ samples for each station), where the black thin lines show the standard deviation, and the thick dark gray lines show the 5 to 95 percentiles. The light gray bars show the range of the minimum to the maximum simulated values at each of the sample points over each month 
resolution models are required. A model setup for the region around Flåtegrunnen in $32 \mathrm{~m}$ horizontal resolution was therefore established following the procedure described by Broch et al. (2013). Vertical layers ranging in thickness from $0.5 \mathrm{~m}$ near the surface to $25 \mathrm{~m}$ at greater depths were used. The simulation time step was $6 \mathrm{~s}$. The ammonium was released from 3 to $15 \mathrm{~m}$ depth. The release rates were calculated from reported feed usage (Fig. 2) using a conversion factor of $0.025 \mathrm{~kg}$ ammonium released per $\mathrm{kg}$ dry fish feed used (adapted from Wang et al. 2012). A comparison between empirical measurements and modeled concentrations is provided in Fig. 3 . The simulation results were used to make 2D spatial maps of the maximum concentrations of ammonium for April and September 2013. Maps of the probability for ammonium concentrations between 0 and 25, 25 and 75 , and 75 and $100 \%$ of the model domain maximum were made for April and September. Simulated hourly values were used, with the concentrations normalized with respect to the highest concentration for each hourly time interval. All values for simulated ammonium concentrations are presented as depth-integrated $(0-15 \mathrm{~m})$ values, except where depth $<15 \mathrm{~m}$, where the values were integrated from the surface to the bottom.

\section{RESULTS}

\section{Spatial dynamics throughout the production cycle}

The CTD information demonstrated that the water body was comparable between sampling stations
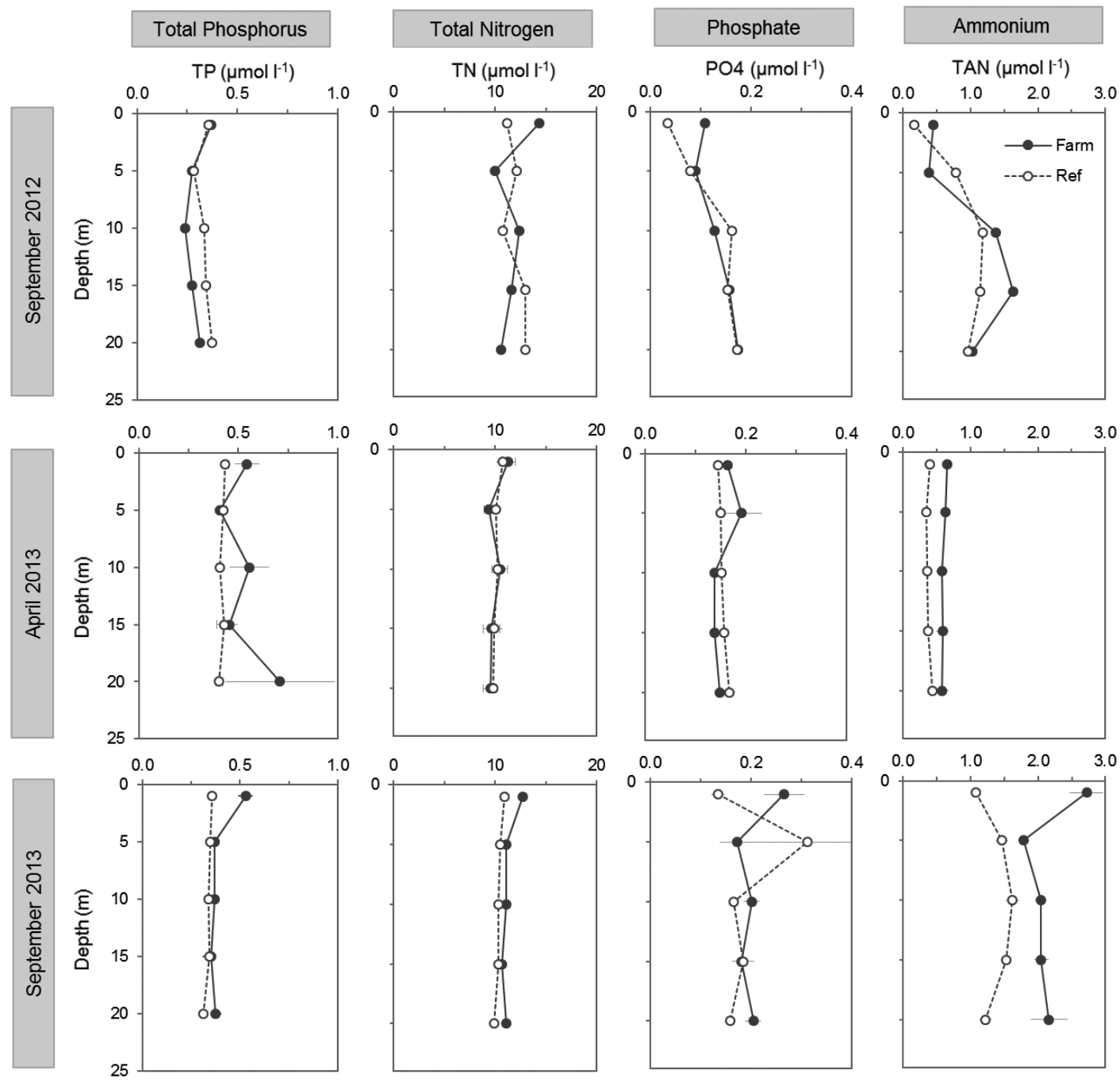

Fig. 4. Seasonal variability in nutrient concentrations at the farm (closed circles, Stns 2 and 3) and reference (open circles, Stns 15 and 16) locations. Values are presented as mean \pm SE for April and September 2013 ( $\mathrm{n}=3$ per station), and as averages excluding SE for September 2012 ( $\mathrm{n}=1$ per station, see also Table 1) 


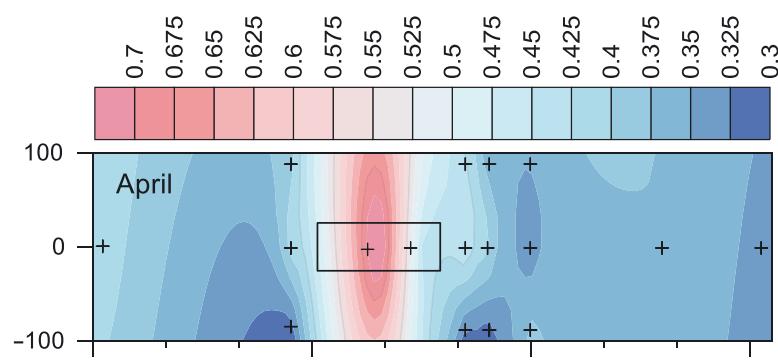

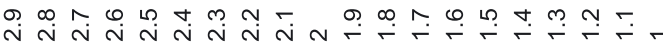

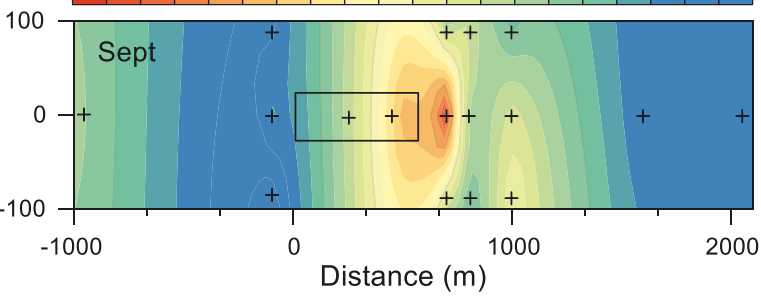

Fig. 5. Spatial distribution of the waste plume as observed with empirical measurements. Contour plots show average depth-integrated ammonium (total ammonium nitrogen in $\mu \mathrm{mol} \mathrm{l}^{-1}$ ) concentrations in and around the salmon farm during sampling campaigns in April and September 2013. The rectangle represents the salmon farm ( 7 cages), and the crosses indicate the sampling stations (see Fig. 1C,D). The contours were interpolated using the kriging method (Surfer, V11 Golden Software). The legends specify ammonium concentrations for the graph immediately below. Note that the color scalings are different in the 2 plots

within each sampling campaign, indicating that variations in nutrient concentrations could be attributed to farm-induced effects and were not the result of differences in water column properties between stations. The stratification interval of the water column was observed at $10 \mathrm{~m}$ depth in September 2012 and $35 \mathrm{~m}$ depth in April 2013, while no clear stratification of the upper $40 \mathrm{~m}$ was observed in September 2013. Temperatures were $11-13^{\circ} \mathrm{C}$ (September 2012), $4-6^{\circ} \mathrm{C}$ (April 2013) and $12-15^{\circ} \mathrm{C}$ (September 2013), and salinity was 25-30 ppt (September 2012), 32-34 ppt (April 2013) and 24-33 ppt (September 2013). During the sampling campaigns, the predominant current direction at the farm was south-west $\left(210-230^{\circ}\right)$ and east $\left(90-110^{\circ}\right)$, depending on the tidal cycle, and it was confirmed that current direction was unidirectional during the systematic water sampling campaigns. Current direction at 5 and $20 \mathrm{~m}$ differed slightly, with a larger angle for the $5 \mathrm{~m}$ depth observations. Average daily current speeds varied between 2 and $9 \mathrm{~cm} \mathrm{~s}^{-1}$, and were generally lower in April compared to September.

Ambient dissolved nitrogen concentrations varied throughout the year (Fig. 2). Enhancement of ammonium (TAN) concentrations in close proximity of the fish cages was observed in April and September 2013 (nested ANOVA $\alpha=0.05$, see the Supplement at www.int-res.com/articles/suppl/q010p385_supp.pdf). On average, 1.6 times higher ammonium values were observed at the farm compared to the reference stations, and differences were observed for all depth intervals (Fig. 4). Higher ammonium values did not result in significantly higher TN concentrations, with the exception of the surface water concentrations in September 2013 which were slightly elevated, likely due to enhanced ammonium concentrations. At the same time, significantly higher total and dissolved phosphorus (TP, DIP) values were observed in the surface water in September 2013. However, apart from ammonium, no significant increase of nutrients (TN, TP, $\mathrm{NO}_{3}, \mathrm{NO}_{2}, \mathrm{PO}_{4}$ ) was observed between the stations close to the fish cages and the reference stations (Fig. 4; see Supplement). Additionally, statisti-
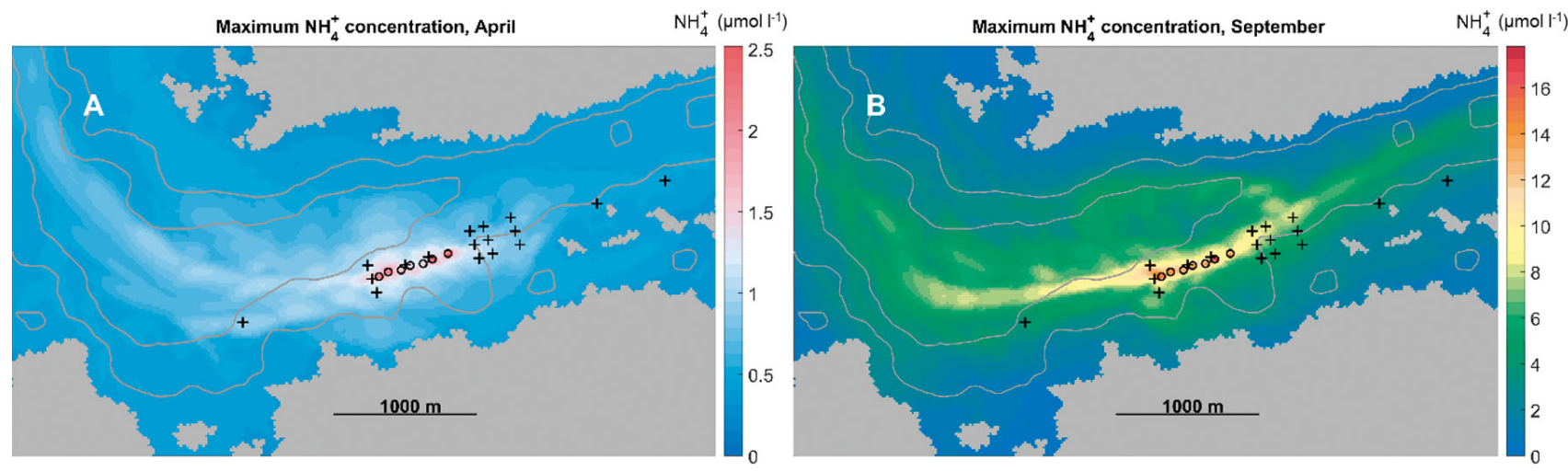

Fig. 6. Time-integrated maximum ammonium concentrations as observed for each grid cell in the simulation model during the entire month of (A) April and (B) September. Circles indicate the salmon cages, and black crosses are the sampling stations as outlined in Fig. 1. The plots show a subregion of the model domain used. The color maps correspond qualitatively with those used in Fig. 5 


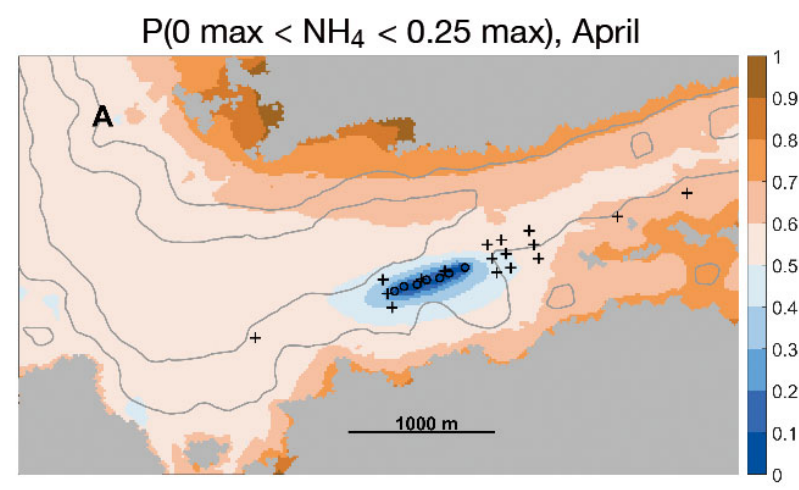

\section{$\mathrm{P}\left(0\right.$ max $<\mathrm{NH}_{4}<0.25$ max $)$, September}

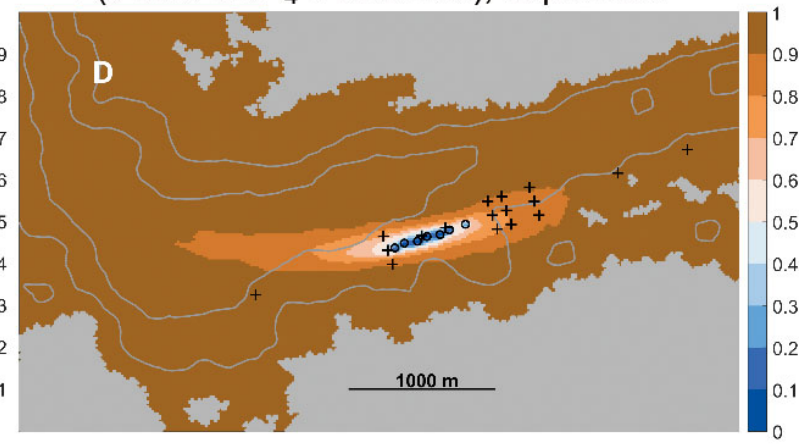

$\mathrm{P}\left(0.25 \max <\mathrm{NH}_{4}<0.75 \max \right)$, April

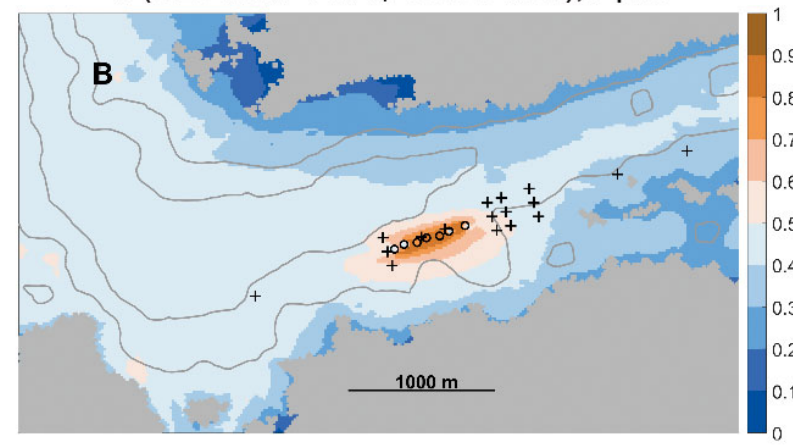

$\mathrm{P}\left(0.25 \max <\mathrm{NH}_{4}<0.75 \max \right)$, September
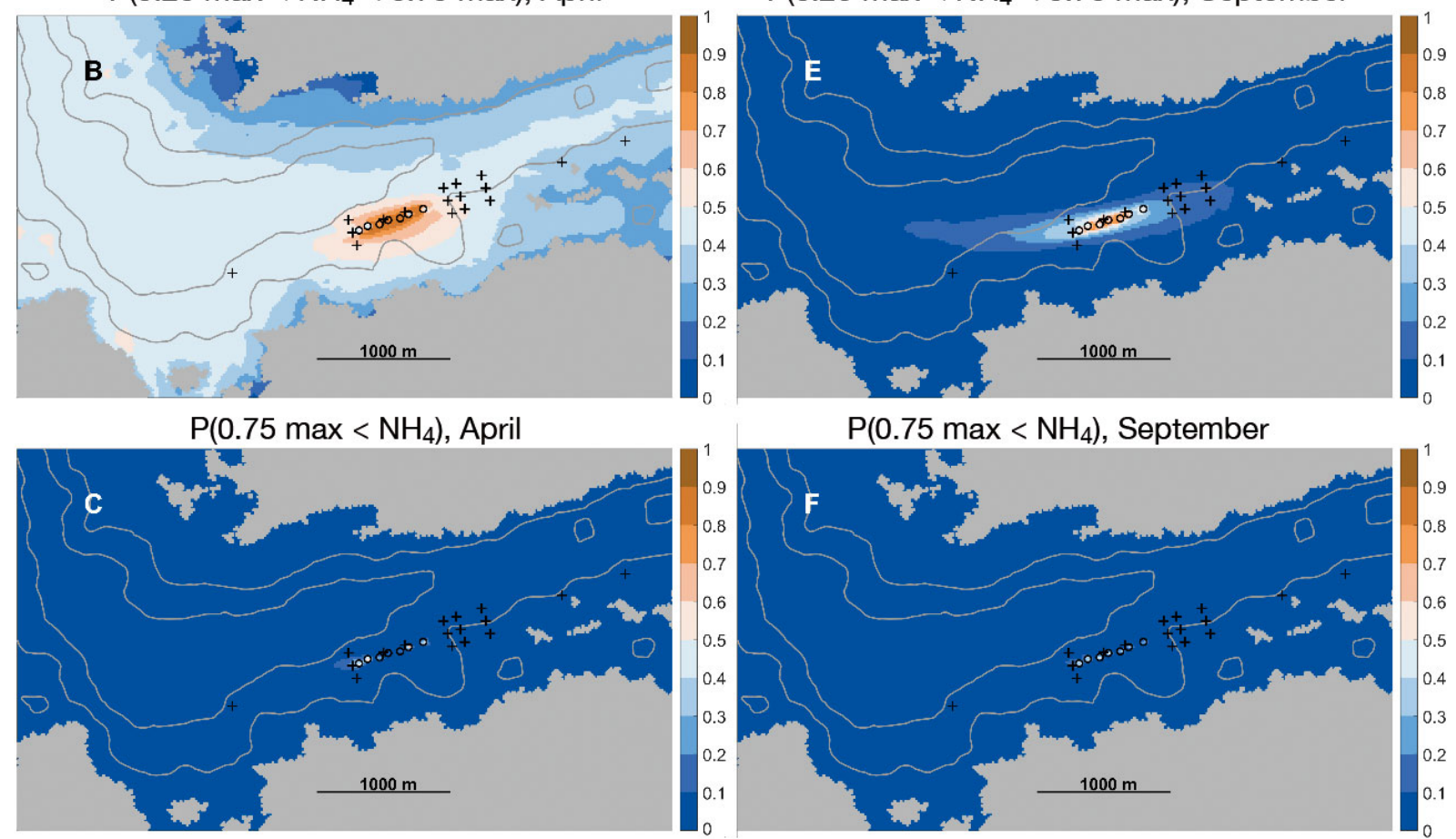

$\mathrm{P}\left(0.75 \max <\mathrm{NH}_{4}\right)$, September

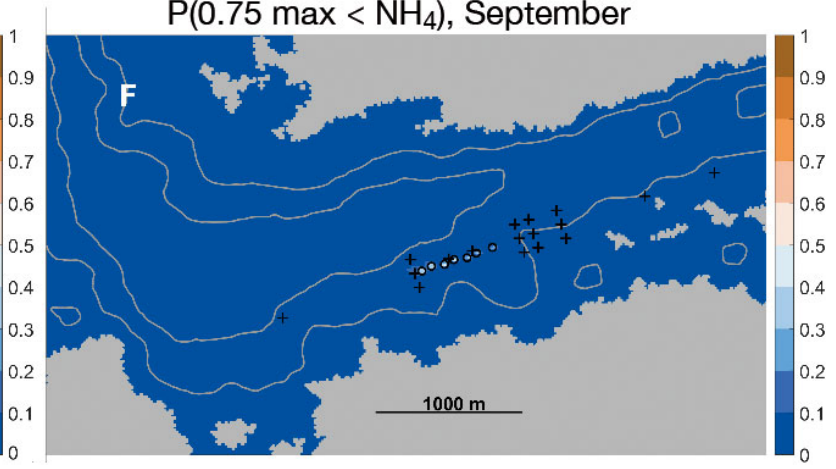

Fig. 7. Probability maps for simulated ammonium dilution in (A-C) April and (D-F) September. The colors represent the (temporal) probability of an ammonium concentration in a grid cell at (A,D) $<25 \%,(\mathrm{~B}, \mathrm{E})$ between 25 and $75 \%$ or $(\mathrm{C}, \mathrm{F})>75 \%$ of the maximum concentration in the model domain for each (hourly) time sample
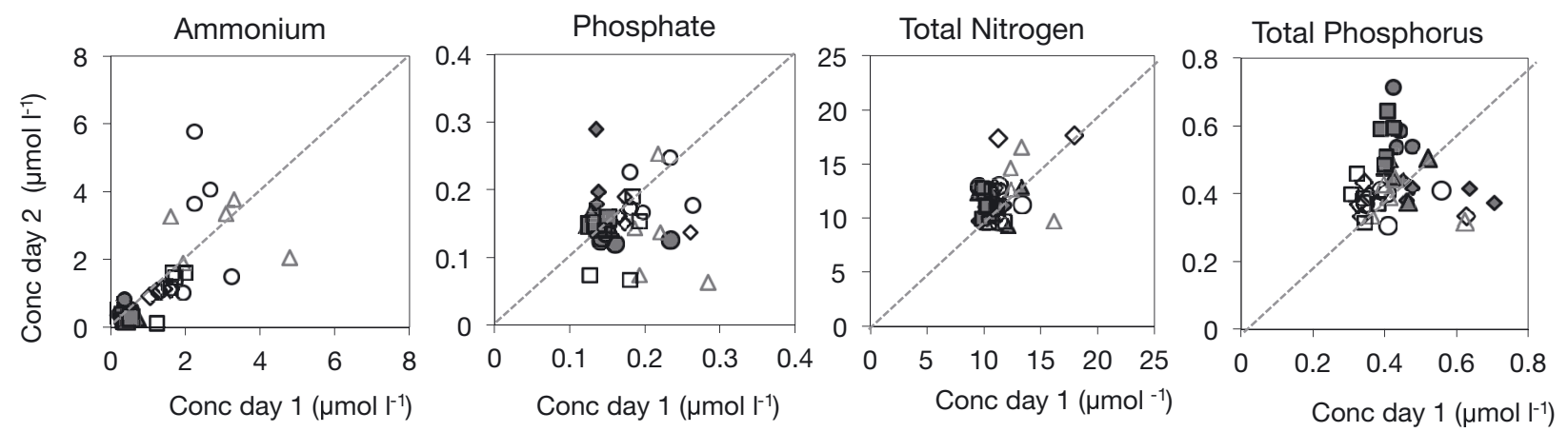

Fig. 8. Between-day variability. Similarity in nutrient concentrations taken on 2 consecutive days at 4 sampling stations $(0=$ Stn 3-farm, $\diamond=$ Stn 1-100 m west, $\Delta=$ Stn 4-100 m east, $\square=$ Stn 16-ref). Each symbol presents the average for 1 depth interval based on triplicate measurements. Solid $(\bullet)$ and open $(\circ)$ symbols represent the sampling campaigns in April and September 2013, respectively. The diagonal line indicates a similarity index of 1 

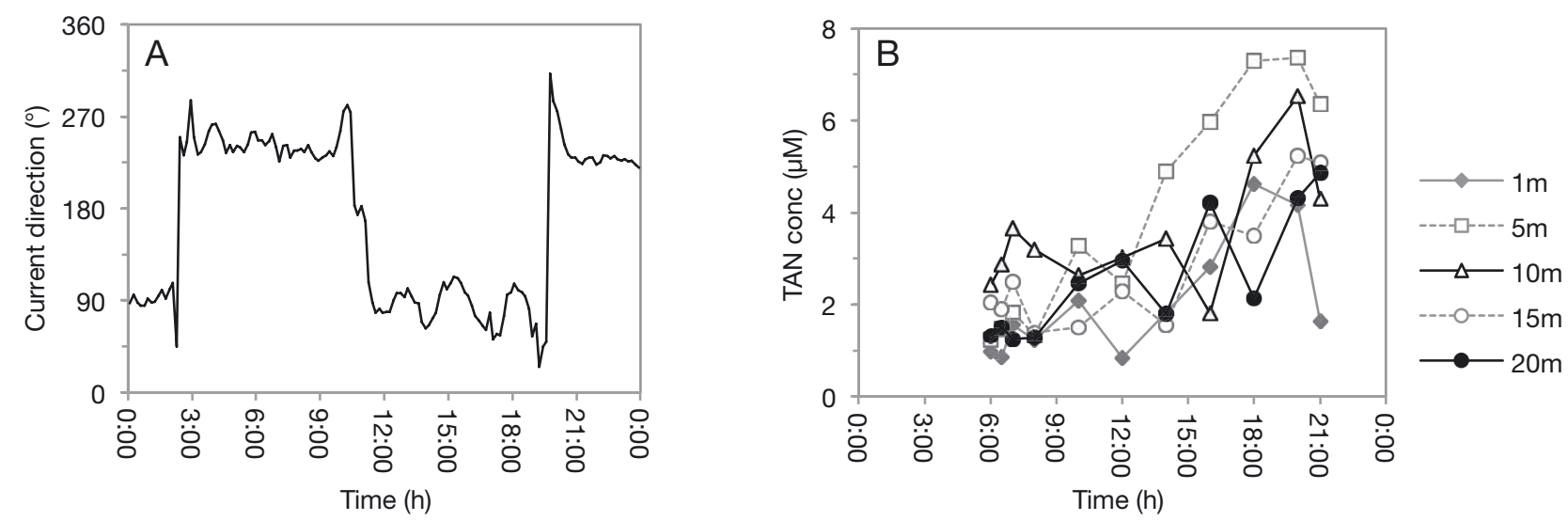

Fig. 9. Within-day variability in (A) current direction measured at $5 \mathrm{~m}$ depth and (B) average ammonium concentrations measured directly beside a salmon net pen at the 5 sampling depth intervals in September 2013. Ammonium sampling was performed during daylight hours

cal analysis for ammonium showed that the nested term was significant for most depth intervals, indicating that variability was high between stations, both within the farm as well as for the reference stations.

Transect results indicated that the ammonium concentrations decreased significantly within short distances from the cages (Fig. 5). In September 2013, the highest concentrations were observed at Stn 4 (100 m east) with a maximum concentration of (mean $\pm \mathrm{SE}) 4.8 \pm 0.2 \mu \mathrm{M}$ detected at $15 \mathrm{~m}$ depth. The average depth-integrated concentration for 4 was $2.9 \pm$ $0.3 \mu \mathrm{M}, 2.1$ times higher than the concentrations at the reference sites in September 2013. For all other up- and down-current stations, no elevation of ammonium beyond background values could be detected. Distribution data of depth-integrated TN, TP and $\mathrm{PO}_{4}$ concentrations did not show any spatial pattern (data not shown).

The numerical model results also indicated that the ammonium diluted sharply away from the fish cages, mainly along an east-west axis (Fig. 6). Maximum concentrations were observed within the cages, but model output also pointed out that enhanced ammonium concentration could be found more than $1000 \mathrm{~m}$ away from the farm (Fig. 6). Fig. 7 demonstrates, however, that the probability of observing these high concentrations is low, indicating that they will only rarely occur at these large distances. The probability of concentrations close to the maximum (>75\%; Fig. 7) was found in the immediate vicinity of the cages, and the majority of enhanced values (between 25 and $75 \%$ of maximum values; Fig. 7) were recorded within a few hundred meters of the fish cages. The model results further indicated that the plume of ammonium from the fish farm was transported westerly from the farm (Figs. $6 \& 7$ ).

\section{Between-day variation}

Nutrient concentrations varied for measurements carried out during 2 consecutive days at the same stations (Fig. 8). Differences were irrespective of depth interval, and observed concentrations were both above and below the 'similarity index' (Fig. 8) within season and station. Depth- and stationintegrated averages for standardized variation showed that concentrations between 2 consecutive sampling days were 38 and $40 \%$ for ammonium, 17 and $56 \%$ for phosphate, 12 and $16 \%$ for TN, and 31 and $21 \%$ for TP in April and September, respectively. Significantly higher variation in ammonium concentrations was observed at the farm station $(62 \pm 12 \%)$ compared to the reference station $(28 \pm 6 \%, t$-test, $\mathrm{p}<$ $0.05)$, while there was no statistical difference in standardized variance between the farm and reference station for the other nutrients (independent $t$-tests for $\mathrm{PO}_{4}, \mathrm{TN}$ and TP, $\mathrm{p}>0.05$ ). In September, the highest ammonium values were observed at $15 \mathrm{~m}$ depth at the down-current station (Stn 4, $100 \mathrm{~m}$ ) during Day $1(4.8 \pm 0.2 \mu \mathrm{M})$, while the following day maximum values were recorded at $10 \mathrm{~m}$ depth at the farm station (Stn $3 ; 5.8 \pm 0.4 \mu \mathrm{M}$ ).

\section{Within-day variation}

Ammonium concentrations close to a fish cage (2-3 $\mathrm{m}$ distance) increased throughout the day, particularly from 12:00 h onwards (Fig. 9B). Samples were collected on the west side of a cage, indicating that water was delivered directly from the cage when the current direction was $270^{\circ}$ (03:00-10:00 $\mathrm{h}$ and after 19:30 h), whereas with an opposite current 
Table 2. Review of nutrient enhancement in the near-field (next to cages) and along a transect away from fish cages (medium to farfield) for the 2 main cage culture types. SS: standing stock, TN: total nitrogen, TP: total phosphorus, DON: dissolved organic nitrogen, DOP: dissolved organic phosphorus, DIN: dissolved inorganic nitrogen, DOC: dissolved organic carbon, POP: particulate organic phosphorus, $\mathrm{x}$ : values were not reported, Ref $=$ distance to nearest reference site

\begin{tabular}{|c|c|c|c|c|c|c|}
\hline $\begin{array}{l}\text { Culture type } \\
\text { and } \\
\text { production }\end{array}$ & $\begin{array}{l}\text { Mean cur- } \\
\text { rent speed } \\
\quad\left(\mathrm{cm} \mathrm{s}^{-1}\right)\end{array}$ & $\begin{array}{l}\text { Para- } \\
\text { meters }\end{array}$ & $\begin{array}{l}\text { Near-field } \\
\text { enhance- } \\
\text { ment (max) }\end{array}$ & $\begin{array}{c}\text { Medium/ } \\
\text { far-field } \\
\text { enhancement }\end{array}$ & $\begin{array}{l}\text { Description } \\
\text { medium/far- } \\
\text { field transect }\end{array}$ & Source \\
\hline \multicolumn{7}{|l|}{ Salmonids } \\
\hline Max. 3000 t SS & $\begin{array}{c}2.4-8.6 \\
(\max )\end{array}$ & $\begin{array}{c}\mathrm{NH}_{4} \\
\mathrm{NO}_{\mathrm{x}}, \mathrm{PO}_{4} \\
\mathrm{TN}, \mathrm{TP}\end{array}$ & $\begin{array}{l}\text { Yes }(1.6 \times) \\
\text { No } \\
\text { No }\end{array}$ & $\begin{array}{c}\text { Yes (to } 100 \mathrm{~m} \text { ) } \\
\text { No } \\
\text { No }\end{array}$ & $\begin{array}{l}0-100-200-400 \mathrm{~m} \\
\quad \operatorname{Ref}=1000 \mathrm{~m}\end{array}$ & This study \\
\hline Max. 450 t SS & $\begin{array}{c}1.5-3.1 \\
(\max 14.4)\end{array}$ & $\begin{array}{c}\mathrm{NH}_{4} \\
\mathrm{NO}_{x}, \mathrm{PO}_{4}\end{array}$ & $\begin{array}{l}\text { Yes }(6 \times) \\
\text { No }\end{array}$ & $\begin{array}{l}\text { Yes (to } 200 \mathrm{~m} \text { ) } \\
\text { No }\end{array}$ & $\begin{array}{c}0-50-200-300 \mathrm{~m} \\
\operatorname{Ref}=400 \mathrm{~m}\end{array}$ & Sanderson et al. (2008) \\
\hline Max. 450 t SS & $\begin{array}{l}(\min 2.5 \\
\max 7.5)\end{array}$ & $\begin{array}{c}\mathrm{NH}_{4} \\
\mathrm{DON} \\
\mathrm{DOP}_{1} \mathrm{PO}_{4} \\
\mathrm{NO}_{3}\end{array}$ & $\begin{array}{l}\text { Yes }(3.5 \times) \\
\text { Yes }(2 \times) \\
\text { No } \\
\text { No }\end{array}$ & $\begin{array}{l}\text { Yes (to } 40 \mathrm{~m} \text { ) } \\
\text { Yes (to } 40 \mathrm{~m} \text { ) } \\
\text { No } \\
\text { No }\end{array}$ & $\begin{array}{l}0-40-190 \mathrm{~m} \\
\text { Ref }=650 \mathrm{~m}\end{array}$ & Navarro et al. (2008) \\
\hline $235 \mathrm{t} \mathrm{yr}^{-1}$ & $\begin{array}{c}2.7-3.5 \\
(\max 14.4)\end{array}$ & $\begin{array}{c}\mathrm{NH}_{4} \\
\mathrm{NO}_{\mathrm{x}} \mathrm{PO}_{4}\end{array}$ & $\begin{array}{l}\text { Yes } \\
\text { No }\end{array}$ & $\mathrm{x}$ & $\mathrm{x}$ & Wildish et al. (1993) \\
\hline Max. 575 t SS & $\mathrm{x}$ & $\begin{array}{c}\mathrm{NH}_{4} \\
\mathrm{NO}_{\mathrm{x}}, \mathrm{PO}_{4}\end{array}$ & $\begin{array}{l}\text { Yes }(5.2 \times) \\
\quad \text { No }\end{array}$ & $\begin{array}{l}\text { Yes (to } 20 \mathrm{~m} \text { ) } \\
\text { No }\end{array}$ & $\begin{array}{l}0-5-10-20-50 \mathrm{~m} \\
\text { Ref }=300 \mathrm{~m}\end{array}$ & Merceron et al. (2002) \\
\hline \multicolumn{7}{|l|}{ Seabream/bass } \\
\hline $250 \mathrm{t} \mathrm{yr}^{-1}$ & $\mathrm{x}$ & $\begin{array}{l}\mathrm{DIN} \\
\mathrm{PO}_{4} \\
\mathrm{DOC}\end{array}$ & $\begin{array}{c}\text { Yes }(5.4 \times) \\
\text { Yes }\end{array}$ & $\begin{array}{l}\mathrm{x} \\
\mathrm{x}\end{array}$ & Ref $=1000 \mathrm{~m}$ & La Rossa et al. (2002) \\
\hline 90-130 mean SS & $\mathrm{x}$ & $\begin{array}{l}\mathrm{NH}_{4} \\
\mathrm{NO}_{3} \\
\mathrm{NO}_{2} \\
\mathrm{PO}_{4}\end{array}$ & $\begin{array}{l}\text { Yes }(2.6 \times) \\
\text { Yes }(2.0 \times) \\
\text { Yes }(2.0 \times) \\
\text { Yes }(2.7 \times)\end{array}$ & $\begin{array}{l}\text { Yes (to } 50 \mathrm{~m} \text { ) } \\
\text { Yes (to } 50 \mathrm{~m} \text { ) } \\
\text { Yes (to } 50 \mathrm{~m} \text { ) } \\
\text { Yes (to } 50 \mathrm{~m} \text { ) }\end{array}$ & $\begin{array}{c}0-50 \mathrm{~m} \\
\operatorname{Ref}=300 \mathrm{~m}\end{array}$ & $\begin{array}{l}\text { Neofitou \& Klaoudates } \\
(2008)\end{array}$ \\
\hline $350-400 \mathrm{t} \mathrm{yr}^{-1}$ & $\mathrm{x}$ & $\begin{array}{c}\mathrm{NH}_{4} \\
\mathrm{PO}_{4} \\
\mathrm{NH}_{4}, \mathrm{PON} \\
\mathrm{PO}_{4}, \mathrm{POP}\end{array}$ & $\begin{array}{l}\text { Yes }(4 \times) \\
\text { Yes }(4.5 \times) \\
\text { Yes }(x)\end{array}$ & $\begin{array}{l}\text { Yes (to } 30 \mathrm{~m} \text { ) } \\
\text { No }\end{array}$ & $\begin{array}{l}0-7-15-30 \mathrm{~m} \\
\text { Ref }=2000 \mathrm{~m}\end{array}$ & $\begin{array}{l}\text { Mantzavrakos et al. (2007) } \\
\text { Pitta et al. (2006) }\end{array}$ \\
\hline
\end{tabular}

direction (12:00-19:30 h), water from the neighboring cage $50 \mathrm{~m}$ westwards was sampled (Fig. 9A). The maximum $(20: 00 \mathrm{~h})$ depth-integrated average concentrations were 4.5 times higher than the minimum (06:00 h) concentrations. Maximum ammonium values were observed at $10 \mathrm{~m}$ depth in the early morning and at $5 \mathrm{~m}$ depth later during the day (Fig. 9B). As for the measured results, the simulation results also indicated a diurnal variability driven largely by the tidal movement (data not shown).

\section{DISCUSSION}

The results in this study indicate that the spatial dispersal of nutrient effluents from a commercial Norwegian Atlantic salmon farm was limited to a few hundred meters away from the farm. We also found that the short-term temporal variability (between and within days) in effluent concentrations can be signif- icant, which has implications for how nutrient enrichment due to aquaculture activities may be assessed. The results of this study are important for understanding the environmental effects of salmon farming and for evaluating the potential for IMTA.

\section{Waste plume dynamics}

Ammonium concentrations were enhanced in the proximity of Atlantic salmon cages located in a dynamic coastal area in Norway, whereas enrichment with other soluble metabolic byproducts such as orthophosphate or dissolved particulate wastes was not detected. This is in line with fish metabolism, where ammonium is a by-product from protein catabolism and is continuously excreted, while orthophosphate is only excreted in excess of metabolic requirements (Bureau et al. 1999). Although ammonium is continuously excreted, the level of excretion 
can be variable throughout the day, normally in relation to feeding times (Brett \& Zala 1975). A literature review indicated that ammonium levels around fish cages are often enhanced, while results on phosphate vary (Table 2). No enhancement in dissolved particulate nutrients was observed, which is in agreement with Brager et al. $(2015,2016)$, who showed that the enhancement of total particulate matter concentrations was highly localized around salmon farms in Canada and Norway, including the same farm that we studied here.

Discharge levels depend on the standing stock of salmon and feeding levels, and thus vary throughout the production cycle. No elevation in ammonium concentrations was detected in the first year of the production cycle. However, increasing biomass resulted in increased ammonium values (up to $0.2 \mu \mathrm{M}$ above background concentrations) in April of the second year and to a maximum of $0.8 \mu \mathrm{M}$ above background at peak production. This is considerably lower compared to Sanderson et al. (2008), who reported a maximum of $8 \mu \mathrm{M}$ ammonium (generally $0.6-4.2 \mu \mathrm{M}$ ) above background values in close vicinity of salmon cages in Scotland. As ambient nutrient concentrations vary seasonally (Sætre 2007; Figs. 2 \& 3), the relative contribution of waste nutrients to ambient nutrients was similar between April and September (1.6 times). This is lower compared to other studies in salmon and seabass/bream farming, which have reported between 2.2 and 6 times higher ammonium values near fish cages (Table 2). The relatively low enrichment detected in our study is inconsistent with results from the past studies and is likely related to a higher rate of dispersion. This is supported by the medium/far-field measurements which demonstrated that concentrations at $100-400 \mathrm{~m}$ were similar to background values. The only exception was the high ammonium concentration measured at 100 m directly down-current (easterly direction) of the farm (Stn 4) in September 2013. The model simulation results further indicate that ammonium concentrations sharply decreased away from the fish farm due to physical dilution and uptake by phytoplankton (Figs. 6 \& 7). Occasionally high simulated concentrations were found further from the farm than what was apparent from the field data (Fig. 6). This highlights the spatial and temporal limitations of empirical sampling, as one might not sample during the time period when waste plume dispersal is at its maximum (Figs. 6 \& 7 are based on continuous simulation results for the entire months of April and September) The modeling results indicate that the waste plume extended more in a westerly than an easterly direction. This could not be confirmed or rejected by the empirical sampling results, as the sampling campaigns focused on the waste plume dynamics on the eastern side of the farm. This rapid decrease in waste nutrient concentrations are in line with those published by Merceron et al. (2002), Lander et al. (2004) and Navarro et al. (2008), who reported that high concentrations of dissolved nutrients observed next to the cages were diluted to background levels after $20-50 \mathrm{~m}$ from the cages. Sanderson et al. (2008) reported enhanced ammonium concentrations at 200-300 m, but principally within $50 \mathrm{~m}$ down-current from the cages. It is interesting to note that the latter study also demonstrated that ammonium plumes from fish cages may show non-linear patterns with higher concentrations observed further from the farm compared to measurements beside net pens. This is similar to the pattern observed in our study, where in September (2013), 1.4 times higher values were observed at the $100 \mathrm{~m}$ (Stn 4) compared to the measurements close to the cages. Furthermore, Sanderson et al. (2008) suggested that this is related to the complex near-field hydrodynamics in proximity of fish cages. However, it should be noted that the bathymetry in their study area was somewhat more complicated compared to our study site.

As the level of enrichment is low, the question arises how this relates to natural and farm-induced temporal variability. Patchiness of ambient water bodies may cause fluctuations in water quality parameters on short-term temporal and small spatial scales. In order to be able to distinguish farm-induced effects from environmental fluctuations, it is therefore important to assess background environmental variability (Fernandes et al. 2001). The absence of (accurate) in situ ammonium sensors for seawater necessitates discrete water sampling, which limits the number of samples both in time and space (Jansen et al. 2016). Information on short-term temporal variability is therefore sparse. The average daily variation in measured ammonium concentrations $(28 \%$ at the reference station and $62 \%$ at the farm station) indicates that the estimated level of impact may vary strongly from day to day. Higher variation at the farm stations is not surprising, as waste fluxes are not expected to exit the cages as a continuous and homogenous waste stream (Brager et al. 2016), and the estimated increased nutrient enhancement varied up to 2 times from day to day. Jansen et al. (2016) showed for highly variable environmental and current conditions in the Bay of Fundy (Canada) that daily variation in ammonium concentrations close to an IMTA farm could vary signifi- 
cantly. Estimates from the numerical model also suggest significant daily variation. Diurnal variation of nutrient concentrations measured directly besides the cages was greater than between days; concentrations detected in the evening were 3.5 times higher than early in the morning. As diurnal variability in background nutrient concentrations was not measured, we were unable to determine whether higher concentration in the evening was caused by lower uptake by phytoplankton or by increased release by the fish. The extensive seasonal sampling (spatial grid) was generally performed in the morning. This might, however, imply that the observed enhancement close to the cages compared to the reference stations (1.6 times) was not the maximum due to lower excretion of effluents by the fish during the morning hours, and this may explain the larger spatial extent of the plume observed by the model, as Fig. 6 shows maximum values. Generally, the highest ammonium concentrations are expected $2 \mathrm{~h}$ after the start of feeding, corresponding with postprandial peaks in the output of wastes from the fish after feeding (Brett \& Zala 1975). This was indeed observed by Sanderson et al. (2008), who reported a doubling in ammonium values $2-3 \mathrm{~h}$ after fish feeding commenced, as well as by Karakassis et al. (2001) who showed a 7 -fold increase for ammonium and phosphate approximately $3 \mathrm{~h}$ after feeding started. In our study, values remained low until $5 \mathrm{~h}$ after initiation of feeding until they started to rise. The highest values were observed at $5 \mathrm{~m}$ and are likely linked to the swimming depth of the fish, as waste release (vertically) is expected to occur at the depth interval with maximum fish biomass (Oppedal et al. 2011). Maximum $\mathrm{NH}_{4}$ and DON release at $5 \mathrm{~m}$ depth was also reported by Navarro et al. (2008), and Sanderson et al. (2008) noted that low levels of ammonium were observed at $10 \mathrm{~m}$ depth compared to sampling at $4 \mathrm{~m}$ depth. Preferred swimming depths and densities of salmon culture vary on diurnal and daily scales, as they are the result of active trade-offs among environmental influences (e.g. temperature, oxygen) and an array of internal motivational factors such as feed and perceived threats (Oppedal et al. 2011).

\section{Environmental effects}

Despite the high fish biomass and thus large amounts of solid and soluble wastes that entered the water, the quick dispersal of nutrients suggests that the farm studied here is not causing significant degradation of surface water quality. Dissolved nutri- ent levels, however, do not tell the full story on the state of a system, as nutrients are quickly assimilated by primary producers, especially in nutrient-limited systems and/or seasons. Olsen et al. (2014) showed, for example, that higher additions of inorganic $\mathrm{N}$ and $\mathrm{P}$ in a coastal lagoon resulted in higher chl $a_{\text {, phyto- }}$ plankton and particulate organic nitrogen, phosphorus and carbon (PON, POP and POC) concentrations while DIN and DIP concentrations remained stable, and based on those results suggested PON concentrations as an indicator for planktonic state in the system. To what degree increased input of dissolved nutrients affected the biomass and production of autotrophs and the microbial food web was not investigated in the present study. The numerical model includes uptake processes for phytoplankton, and fluorescent profiles (CTD) and TN and TP measurements were similar across stations and did not point towards enhancement of phytoplankton biomass. Based on these and other results (Husa et al. 2014, H. M. Jansen unpubl data) it was recently concluded in the risk analysis for Norwegian aquaculture that salmon farming does not yet cause unacceptable environmental degradation in pelagic waters (Taranger et al. 2015). However, this may however change with the projected increase from 1.3 Mt salmon production at present to $6 \mathrm{Mt}$ in 2050 (Olafsen et al. 2012)

The projected growth has the potential to increase both farm-scale (local) impacts as farms will continue to grow in size, as well as regional impacts due to higher overall nutrient release into the coastal waters. While nutrient enhancement at the farm scale has been observed in a number of studies (Table 2), fewer studies have reported regional-scale effects. Skogen et al. (2009) and Husa et al. (2014) found little evidence that aquaculture has a regional impact on the ecological status of a large fjord in Norway (Hardanger fjord) despite the high production level (70000 t yr $\mathrm{r}^{-1}, 87.5 \mathrm{t} \mathrm{km}^{-2} \mathrm{yr}^{-1}$ ). Bay-wide effects on pelagic water quality, indicating that fish farming does have the potential to influence ecosystem functioning at regional scales, were reported by Nordvarg \& Johansson (2002) and Pitta et al. (2005). This demonstrates the need for evaluating aquaculture effects at larger spatial scales in Norwegian coastal waters during the coming decades when production is projected to increase 5-fold, thereby taking into account the cumulative fish production of a region, size of the area and hydrodynamics (water volumes, tidal exchange, currents, water retention times). Simulation models can be useful while evaluating regional-scale effects. Furthermore, developments in 
salmon culture may also change the amount and forms of waste nutrients released to the environment. Incorporation of more plant-based ingredients in fish feed, for example, stimulates protein sparing mechanisms in salmon resulting in decreasing DIN release rates (Wang et al. 2013). Modeling the fate of wastes from fish farming largely relies on predictions for the amount of solid and soluble waste nutrients being released. There seems to be no general agreement on the models and underlying assumptions for waste release from salmon aquaculture (Bergheim \& Braaten 2007), which indicates that a revision is required, including the physiological response of salmon to new diets.

Nutrient excretion from fish farms has the largest impact in periods when primary production is nutrient limited, which typically occurs just after the spring bloom until the beginning of autumn when light becomes limiting again. While evaluating environmental consequences, one should carefully consider the different forms of DIN, as the different nitrogen forms occur in balance, and both nitrate and ammonium are absorbed by primary producers. In the current study, we have only presented the comparison between farm and ambient ammonium concentrations, as ammonium was the main constituent DIN in April and September 2013. Hence estimated enhancement was similar for ammonium or DIN concentrations (data not presented). However, as indicated in Fig. 2, the total DIN concentrations are high in winter and are then dominated by nitrate $\left(\mathrm{NO}_{3}\right)$ rather than ammonium concentrations, corroborated also by the simulation results. In winter, primary production is light limited rather than nutrient limited, which means that farm impacts will be different during those seasons. Furthermore, in September 2013, ambient nitrate concentrations were low compared to 2012. Annual variations are common, and low nutrient concentrations in September 2013 were observed for many regions along the Norwegian coastal zone (monitoring program ØKOKYST, www.miljodirektoratet. no/no/Tema/Miljoovervakning/Naturovervaking/ Hav-og-kyst/Okoystemovervaking-i-kystvann/). Assessing the environmental impact strongly depends on the background concentrations, which indicates that with a similar waste nutrient effluent, relative impact would have been lower in 2012 compared to 2013 with a similar estimated nutrient release from the fish cages.

The dilution processes around fish farms as highlighted in this study demonstrate the importance of careful decisions of spatial alignment of extractive species in IMTA systems in order to obtain maximum productivity and highest bioremediation rates. The potential for seaweed cultivation at this specific site is further addressed by J. Fossberg et al. (unpubl.).

Acknowledgements. This work was supported by grant no. 216201 (EXPLOIT) awarded by the Norwegian Research Council. The Institute of Marine Research facilitated sample collection for the Norwegian case study by proving research vessel time, and we thank the crew of RV 'Brattstrøm' for their assistance and Marine Harvest A/S for providing access to the farming location.

\section{LITERATURE CITED}

Bannister RJ, Valdemarsen T, Hansen PK, Holmer M, Ervik A (2014) Changes in benthic sediment conditions under an Atlantic salmon farm at a deep, well-flushed coastal site. Aquacult Environ Interact 5:29-47

* Bannister RJ, Johnsen IA, Hansen PK, Kutti T, Asplin L (2016) Near- and far-field dispersal modelling of organic waste from Atlantic salmon aquaculture in fjord systems. ICES J Mar Sci 73:2408-2419

* Bergheim A, Braaten B (2007) Modell for utslipp fra norske matfiskanlegg til sjo. Rapport IRIS - 2007/180. International Research Institute of Stavanger, Stavanger. www. ancylus.net/Filbas/SFTVekstUtslipp07.pdf

* Brager LM, Cranford PJ, Grant J, Robinson SMC (2015) Spatial distribution of suspended particulate wastes at openwater Atlantic salmon and sablefish aquaculture farms in Canada. Aquacult Environ Interact 6:135-149

* Brager LM, Cranford PJ, Jansen H, Strand Ø (2016) Temporal variations in suspended particulate waste concentrations at open-water fish farms in Canada and Norway. Aquacult Environ Interact 8:437-452

* Brett JR, Zala CA (1975) Daily pattern of nitrogen excretion and oxygen consumption of sockeye salmon (Oncorhynchus nerka) under controlled conditions. J Fish Res Board Can 32:2479-2486

Broch OJ, Ellingsen IH, Forbord S, Wang X and others (2013) Modelling the cultivation and bioremediation potential of the kelp Saccharina latissima in close proximity to an exposed salmon farm in Norway. Aquacult Environ Interact 4:187-206

Brooks KM, Mahnken CVW (2003) Interactions of Atlantic salmon in the Pacific northwest environment. II. Organic wastes. Fish Res 62:255-293

*Bureau DP, Cho CY (1999) Phosphorus utilization by rainbow trout (Oncorhynchus mykiss): estimation of dissolved phosphorus waste output. Aquaculture 179:127-140

Chopin T, Sawhney M, Bastarache S, Shea R and others (2005) Diversifying for sustainability: the advantages of fish/seaweed/shellfish integrated aquaculture. Phycologia 44:20-21

Chopin T, Robinson SMC, Troell M, Neori A, Buschmann AH, Fang JG (2008) Multitrophic integration for sustainable marine aquaculture. In: Jorgensen SE, Fath BD (eds) The encyclopedia of ecology, ecological engineering. Elsevier, Oxford, p 2463-2475

Cloern JE (2001) Our evolving conceptual model of the coastal eutrophication problem. Mar Ecol Prog Ser 210: 223-253

FAO (2016) The state of world fisheries and aquaculture 
2016. Contributing to food security and nutrition for all. FAO, Rome

Fernandes TF, Eleftheriou A, Ackefors $\mathrm{H}$, Eleftheriou $\mathrm{M}$ and others (2001) The scientific principles underlying the monitoring of the environmental impacts of aquaculture. J Appl Ichthyol 17:181-193

Granada L, Sousa N, Lopes S, Lemos MFL (2016) Is integrated multitrophic aquaculture the solution to the sectors' major challenges? A review. Rev Aquacult 8: 283-300

Grasshoff K, Kremling K, Ehrhardt MG (1999) Methods of seawater analysis, 3rd edn. VCH Publishers, Weinheim

Handa A, Min HJE, Wang XX, Broch OJ, Reitan KI, Reinertsen H, Olsen Y (2012) Incorporation of fish feed and growth of blue mussels (Mytilus edulis) in close proximity to salmon (Salmo salar) aquaculture: implications for integrated multi-trophic aquaculture in Norwegian coastal waters. Aquaculture 356-357:328-341

* Holmes RM, Aminot A, Kérouel R, Hooker BA, Peterson BJ (1999) A simple and precise method for measuring ammonium in marine and freshwater ecosystems. Can J Fish Aquat Sci 56:1801-1808

Husa V, Kutti T, Ervik A, Sjotun K, Hansen PK, Aure J (2014) Regional impact from fin-fish farming in an intensive production area (Hardangerfjord, Norway). Mar Biol Res 10:241-252

Islam MS (2005) Nitrogen and phosphorus budget in coastal and marine cage aquaculture and impacts of effluent loading on ecosystem: review and analysis towards model development. Mar Pollut Bull 50:48-61

Jansen HM, Reid GK, Bannister RJ, Husa V and others (2016) Discrete water quality sampling at open-water aquaculture sites: limitations and strategies. Aquacult Environ Interact 8:463-480

Kalantzi I, Karakassis I (2006) Benthic impacts of fish farming: meta-analysis of community and geochemical data. Mar Pollut Bull 52:484-493

Karakassis I, Tsapakis M, Hatziyanni E, Pitta P (2001) Diel variation of nutrients and chlorophyll in sea bream and sea bass cages in the Mediterranean. Fresenius Environ Bull 10:278-283

Kérouel R, Aminot A (1997) Fluorometric determination of ammonia in sea and estuarine waters by direct segmented flow analysis. Mar Chem 57:265-275

Kutti T, Hansen PK, Ervik A, Hoisaeter T, Johannessen P (2007) Effects of organic effluents from a salmon farm on a fjord system. II. Temporal and spatial patterns in infauna community composition. Aquaculture 262: 355-366

La Rosa T, Mirto S, Favaloro E, Savona B , Sarà G, Danovaro $\mathrm{R}$, Mazzola A (2002) Impact on the water column biogeochemistry of a Mediterranean mussel and fish farm. Water Res 36:713-721

Lander T, Barrington K, Robinson S, MacDonald B, Martin J (2004) Dynamics of the blue mussel as an extractive organism in an integrated multi-trophic aquaculture system. Bull Aquacult Assoc Can 104:19-28

Mantzavrakos E, Kornaros M, Lyberatos G, Kaspiris P (2007) Impacts of a marine fish farm in Argolikos Gulf (Greece) on the water column and the sediment. Desalination 210: 110-124

Mente E, Pierce GJ, Santos MB, Neofitou C (2006) Effect of feed and feeding in the culture of salmonids on the marine aquatic environment: a synthesis for European aquaculture. Aquacult Int 14:499-522
Merceron M, Kempf M, Bentley D, Gaffet JD, Le Grand J, Lamort-Datin L (2002) Environmental impact of a salmonid farm on a well flushed marine site: I. Current and water quality. J Appl Ichthyol 18:40-50

Navarro N, Leakey RJG, Black KD (2008) Effect of salmon cage aquaculture on the pelagic environment of temperate coastal waters: seasonal changes in nutrients and microbial community. Mar Ecol Prog Ser 361:47-58

Neofitou N, Klaoudatos S (2008) Effect of fish farming on the water column nutrient concentration in a semienclosed gulf of the eastern Mediterranean. Aquacult Res 39:482-490

Neori A, Chopin T, Troell M, Buschmann AH and others (2004) Integrated aquaculture: rationale, evolution and state of the art emphasizing seaweed biofiltration in modern mariculture. Aquaculture 231:361-391

* Nordvarg L, Johansson T (2002) The effects of fish farm effluents on the water quality in the Aland archipelago, Baltic Sea. Aquacult Eng 25:253-279

Olafsen T, Winther U, Olsen Y, Skjermo J (2012) Verdiskaping basert på produktive hav i 2050. Det Kongelige Norske Videnskabers Selskap (DKNVS) og Norges Tekniske Vitenskapsakademi (NTVA). www.sintef.no/globalassets/ upload/fiskeri_og_havbruk/publikasjoner/verdiskapingbasert-pa-produktive-hav-i-2050.pdf

Olsen Y, Reinertsen H, Sommer U, Vadstein O (2014) Responses of biological and chemical components in North East Atlantic coastal water to experimental nitrogen and phosphorus addition-a full scale ecosystem study and its relevance for management. Sci Total Environ 473-474:262-274

\%oppedal F, Dempster T, Stien LH (2011) Environmental drivers of Atlantic salmon behaviour in sea-cages. Rev Aquacult 311:1-18

Parsons TR, Maita Y, Lalli CM (1992) A manual of chemical and biological methods for seawater analysis. Pergamon Press, New York, NY

*Pitta P, Apostolaki ET, Giannoulaki M, Karakassis I (2005) Mesoscale changes in the water column in response to fish farming zones in three coastal areas in the Eastern Mediterranean Sea. Estuar Coast Shelf Sci 65:501-512

* Pitta P, Apostolaki ET, Tsagaraki T, Tsapakis M, Karakassis I (2006) Fish farming effects on chemical and microbial variables of the water column: a spatio-temporal study along the Mediterranean Sea. Hydrobiologia 563:99-108

* Price C, Black KD, Hargrave BT, Morris JA Jr (2015) Marine cage culture and the environment: effects on water quality and primary production. Aquacult Environ Interact 6: 151-174

Quinn GP, Keough MJ (2002) Experimental design and data analysis for biologists. Cambridge University Press, Cambridge

Read P, Fernandes T (2003) Management of environmental impacts of marine aquaculture in Europe. Aquaculture 226:139-163

* Ryther JH, Goldman JC, Gifford CE, Huguenin JE and others (1975) Physical models of integrated waste recycling, marine polyculture systems. Aquaculture 5:163-177

Sætre R (ed) (2007) The Norwegian Coastal Currentoceanography and climate. Tapir Academic Press, Trondheim

Sanderson JC, Cromey CJ, Dring MJ, Kelly MS (2008) Distribution of nutrients for seaweed cultivation around salmon cages at farm sites in north-west Scotland. Aquaculture 278:60-68 
Sarà G (2007) A meta-analysis on the ecological effects of aquaculture on the water column: dissolved nutrients. Mar Environ Res 63:390-408

Sarà G, Scilipoti D, Mazzola A, Modica A (2004) Effects of fish farming waste to sedimentary and particulate organic matter in a southern Mediterranean area (Gulf of Castellammare, Sicily): a multiple stable isotope study $\left(\delta^{13} \mathrm{C}\right.$ and $\left.\delta^{15} \mathrm{~N}\right)$. Aquaculture 234:199-213

Skogen MD, Eknes M, Asplin LC, Sandvik AD (2009) Modelling the environmental effects of fish farming in a Norwegian fjord. Aquaculture 298:70-75

Slagstad D, McClimans T (2005) Modeling the ecosystem dynamics of the Barents Sea including the marginal ice zone: I. Physical and chemical oceanography. J Mar Syst 58:1-18

Soto D (2009) Integrated mariculture - a global review. FAO Fisheries and Aquaculture Tech Pap Book 529. Food and Agriculture Organization of the United Nations, Rome

Taranger GL, Karlsen Ø, Bannister RJ, Glover KA and others (2015) Risk assessment of the environmental impact of Norwegian Atlantic salmon farming. ICES J Mar Sci 72 : 997-1021

Troell M, Halling C, Neori A, Chopin T, Buschmann AH, Kautsky N, Yarish C (2003) Integrated mariculture: asking the right questions. Aquaculture 226:69-90

Editorial responsibility: Adam Hughes,

Oban, UK
Valdemarsen T, Bannister RJ, Hansen PK, Holmer M, Ervik A (2012) Biogeochemical malfunctioning in sediments beneath a deep-water fish farm. Environ Pollut 170: $15-25$

Wang X, Olsen LM, Reitan KI, Olsen Y (2012) Discharge of nutrient wastes from salmon farms: environmental effects, and potential for integrated multi-trophic aquaculture. Aquacult Environ Interact 2:267-283

Wang X, Andresen K, Handå A, Jensen B, Reitan KI, Olsen Y (2013) Chemical composition and release rate of waste discharge from an Atlantic salmon farm with an evaluation of IMTA feasibility. Aquacult Environ Interact 4: 147-162

*Wassmann P, Slagstad D, Riser CW, Reigstad M (2006) Modelling the ecosystem dynamics of the Barents Sea including the marginal ice zone. II. Carbon flux and interannual variability. J Mar Syst 59:1-24

*Wildish DJ, Keizer PD, Wilson AJ, Martin JL (1993) Seasonal-changes of dissolved-oxygen and plant nutrients in seawater near salmonid net pens in the macrotidal Bay of Fundy. Can J Fish Aquat Sci 50:303-311

* Yokoyama H, Abo K, Ishihi Y (2006) Quantifying aquaculture-derived organic matter in the sediment in and around a coastal fish farm using stable carbon and nitrogen isotope ratios. Aquaculture 254:411-425

Submitted: March 2, 2018; Accepted: July 17, 2018

Proofs received from author(s): September 5, 2018 